\title{
Employee Resourcing and Performance of Small and Medium Enterprises in Lagos State, Nigeria
}

\author{
Paul Olusiji Ogunyomi (Corresponding author) \\ Department of Industrial Relations \& Personnel Management \\ Faculty of Business Administration, University of Lagos
}

Tel: +234-70 4-11 0-38 45; +234-706-600-0915Ｅmail: yomipaul@mail.com

Rasheed Kola Ojikutu

Department of Actuarial Science and Insurance

Faculty of Business Administration, University of Lagos

Tel: +234-802- 312-1667Ｅmail: ladiojikutu@yahoo.com

Doi: 10.5296/jebi.v1i1.5346 URL: http://dx.doi.org/10.5296/jebi.v1i1.5346

\begin{abstract}
The objective of this study is to investigate if employee resourcing can be used to predict the performance of Small \& Medium Enterprises (SMEs) in Lagos State, Nigeria. The study adopted the survey research design. Sources of data for the study were primary, secondary, and tertiary. The instruments for the study were in-depth interview and self developed questionnaire using a 4-point Likert scale. A sample of owners/managers of SMEs was drawn from the target population using stratified random sampling techniques. Of the 450 copies of questionnaire administered, 257 copies were returned representing 57 per cent response rate. The reliability test (Cronbach's Alpha) of the instrument yielded 0.60. Data were analyzed using Statistical Package for Social Sciences (SPSS) version 16. The major finding of the study is that although there is a mild association (0.113) between employee resourcing and performance, it is not strong enough to predict the performance of the sampled SMEs. Most of the owners/managers interviewed opined that retaining employees was one of their greatest challenges but not strong enough to determine the level of their performance as they have always envisaged that some of their staff can leave the organization. Hence, adequate provision is made for skilled manpower shortage. Therefore it is recommended that recruitment and selection should be outsourced to firms which specialize in recruiting employees. This will enable the owners/managers to focus more on the core activities of their SMEs.
\end{abstract}

Keywords: Employee resourcing; Organizational Performance; Small and Medium Enterprise. 


\section{Introduction}

Small and medium enterprises (SME) play significant roles in the process of industrialization and economic growth of both developed and developing countries. Aside from creating employment opportunities and increasing per capita income and output, SMEs check rural-urban migration, improve standard of living of citizens, enhance regional economic balance through industrial spread and specifically promote effective resource utilization believed to be critical to promoting economic development and growth, income redistribution, promotion of indigenous entrepreneurs and technology, as well as production of intermediate goods to strengthen inter and intra industrial linkages. However, as laudable as the contributions of SMEs are, Nigeria is yet to fully benefit from the contributions of SMEs owing to a number of reasons among which are poor management of physical, financial and human resources.

Performance in organizational context is broad and has been a subject of study among social scientists from a wide range of disciplines as it is being used synonymously with productivity, efficiency, effectiveness and, more recently, competitiveness (Cooke, 2000). Consensus on performance measurement in the organization is yet to be reached as quantitatively and qualitatively inclined scholars have advocated the use of financial and non-financial criteria respectively. However, one criterion should not be substituted for the other. Both are important in measuring performance if a balanced scorecard is to be obtained (Cooke, 2000; Kaplan \& Norton, 2004). Drucker (1974) does not see much difference between effectiveness and performance hence explains performance in terms of effectiveness and efficiency and stated that effectiveness is a foundation for success while efficiency is the minimum condition for survival after success has been achieved. Furthermore, he posits that efficiency is concerned with doing things right and that it connotes doing better what is already being done. It means a focus on costs, while effectiveness is doing the right thing, thus emphasizing the reason it is a foundation for success.

According to Ukenna, Ijeoma, Anionwu and Olise (2010), firm performance can be evaluated under two main criteria: financial (objective or quantitative) and non-financial (subjective or qualitative). Financial performance includes percentage of sales resulting from new products, profitability, as well as capital employed and returns on assets (ROA) (Hsu, Lin, Lawler \& $\mathrm{Wu}, 2007)$. In addition, Grossman (2000) identifies return on investment (ROI), earnings per share (EPS) and net income after tax (NIAT) as measures of financial performance. In another dimension, organizational performance can be evaluated using non-financial indices such as growth rate, operating efficiency, performance stability, public image and goodwill, as well as staff morale, growth in number of employees, market share, adaptability and innovativeness (Khandwalla, 1995).

There is tendency to see small businesses as smaller versions of large firms, the notion being that whatever strategy adopted in large firms can be transferred and applied wholesomely in small firms. However, Burns (2001) takes a different position and asserts that SMEs should not be seen as smaller versions of large firms since they exhibit a number of fundamental differences, such as absence of economies of scale, liabilities of smallness and newness, as well as scope - these, among others, being also caused by less endowment of human resources (Cardon \& Stevens, 2004; Fitzsimmons \& Fitzsimmons, 2003). 
Many scholars believe that HRM practices that help large organizations to excel can be replicated wholesale in SMEs (see for example, Delery\&Doty, 1996; Marchington\&Grugulis, 2000). However, it has been noted by Cardon and Stevens (2004) that SMEs are unique and have their own internal and external constraints that may not allow practices employed by large-scale organizations to be applicable to them. In the Nigerian context, there is paucity of empirical studies linking employee resourcing to organizational performance in SMEs. This study intends to fill this gap in the literature.

It is worthy of note that during the period of economic recession, while large organizations are faced with massive retrenchment and frozen employment, SMEs find it difficult to recruit and retain good employees (Hornsby and Kuratko, 1990). On the retention of qualified employees, Muse, Rutherford, Oswald and Raymond (2005) note that small businesses cannot afford the required investment in employee welfare that is needed to attract and produce organizational commitment. This has led to employees leaving at short notice thereby causing disruption in operations, especially among manufacturing SMEs. Applebaum and Kamal (2000) assert that small and medium enterprises (SMEs) are more likely to survive and sustain competitive advantage over larger firms by increasing employees' satisfaction, which in turn minimizes labour turnover, absenteeism and reduces production costs.

In spite of the programmes of Nigerian government on the development of SMEs (for example, National Directorate of Employment (NDE), People's bank, National Economic Reconstruction Fund (NERFUND), Bank of Industry (BOI), National Economic Empowerment Development Scheme (NEEDS), Small and Medium Enterprises Development Agency (SMEDAN), the performance of SMEs in Nigeria still leaves much to be desired and a wide gap exists between their contributions to the economy and their full potentials. What could be the cause? Poor management of human and material resources could be assumed to be at the root of all other challenges faced by SMEs. Previously in Nigeria, disproportionate attention was given to financial needs of SMEs at the expense of the other resources. However, this has not yielded the desired results, which implies that SMEs in Nigeria have been operating below their potentials and their benefits to the individuals and the nations have not been fully harnessed. Hence, this study focuses on the human resource needs of small and medium enterprises (SMEs) with a view to suggesting ways of improving their performance. The objective of this paper is to investigate if employee resourcing affects performance of small and medium enterprises in Lagos State, Nigeria.

\section{Literature Review}

\subsection{Conceptual framework}

Although employee resourcing is defined in various ways and different writers have drawn various boundaries around it, the core areas concerned is getting the right people (with appropriate experience, skills, knowledge and other attributes) in the right place at the right time. Armstrong (2012) opines that the term is used as people resourcing, employee resourcing or simply resourcing. It is used to cover employment activities that focus on an organization having the people it needs, and deals with employee turnover and absenteeism 
issues. The core activities of employee resourcing (ER) include human resource planning (HRP) and moving towards recruitment, selection and induction, performance management, learning and development, as well as recognition and reward. These activities, whether by micro, small, medium, private, public, manufacturing, service or multinational organizations, are conducted in a rapidly changing context. It is significantly about aligning the employees with the strategic and operational needs of the organization and ensuring full utilization of the resources. Armstrong (2001:353) notes further that it goes beyond obtaining and keeping the number and quality of the required personnel, but also deals with selecting and promoting people who ' $f i t$ ' the culture and the strategic needs of the organization. In this study, the author defines employee resourcing as the systematic process of realizing the need to plan for people (HRP), acquiring them through recruitment and selection $(\mathrm{R} \& \mathrm{~S})$, retaining through membership motivation (M) and putting them to the most effective use through employee motivation to higher productivity in order to help the organization achieve its goals. According to Armstrong (2001:354), employee resourcing answers two fundamental questions:

i. What caliber of people do we need now and in the foreseeable future in order to strategically position our organization?

ii. What can we do to attract, develop, motivate, and retain them when we need them most? In the above respect, small business owners largely view the staffing of firms as a series of discrete functional activities, such as recruitment, selection and training (Williamson, 2000; Williamson, Cable \& Aldrich, 2002). Whether in small, medium or large organizations, recruitment, selection and retention of personnel (HR) are fundamental functions for successful running of the organization. Small business owners realize that the ability to successfully attract and employ capable individuals into the organization remains one of the keys that determines the success or failure of SMEs, hence adequate attention is being paid to recruitment, selection, motivation, and retention of employees (Williamson, 2000; Williamson, Cable \& Aldrich, 2002; Hornsby \& Kuratko, 2003).

\section{Performance}

\section{Employee Resourcing}

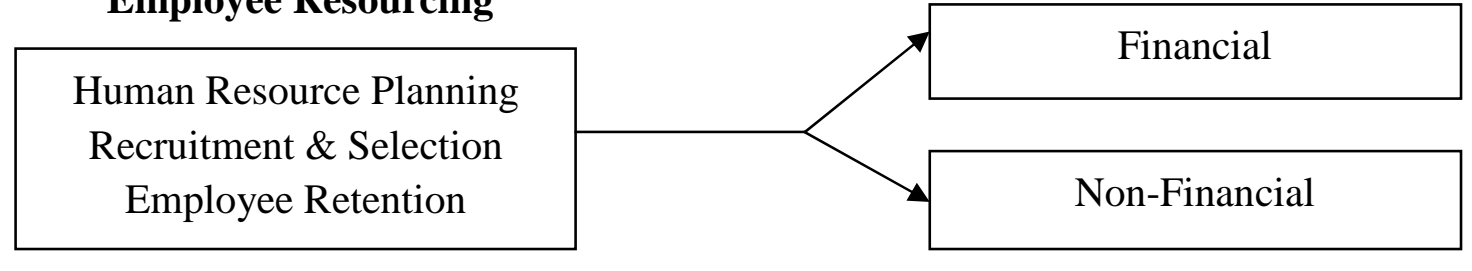

Source: Developed by the author

Figure 1. A model showing the interaction (relationship) between Employee Resourcing and Performance in SMEs

The combined interaction of human resource planning, recruitment \&selection, and employee retention conceptualized as employee resourcing influences performance of the SMEs, which can be financial or non-financial or both. Considering both indices; financial and non-financial is necessary if SMEs are to have a balanced score card. Using financial 
performance alone does not give a balanced view of the organization performance and non-financial criterion alone does not help the organization to get a clear picture of its performance. The interaction may however produce positive or negative effect on the performance of the small and medium enterprises (SMEs).

\subsection{Theoretical framework}

Resource-Based View (RBV): Examining economic units in terms of their resource endowments has a long tradition in economics. The analysis is typically confined, however, to categories such as labour, capital and, perhaps, land. The idea of studying firms as a broader set of resources goes back to the seminal work of Penrose (1959). The Resource-Based View (RBV), as a basis for the competitive advantage of a firm lies primarily in the application of the bundle of valuable interchangeable and intangible or tangible resources at the firm's disposal. To transform a short-run competitive advantage into a sustained competitive advantage requires that these resources are heterogeneous in nature and not perfectly mobile. Effectively, this translates into valuable resources that are neither perfectly imitable nor substitutable without great effort (Barney, 1991:117). If these conditions hold, the bundle of resources can sustain the firm's above average returns. A resource-based view of a firm explains its ability to deliver sustainable competitive advantage when resources are managed such that their outcomes cannot be imitated by competitors, which ultimately creates a competitive barrier. In this study, the resources germane to the competitive advantage of SMEs are employees and how they are managed for higher performance.

\subsection{Empirical research relevant to the study}

Whether in small, medium or large organizations, recruitment, selection and retention of human resources (HR) are fundamental functions for successful running of the organization. Small business owners consider the ability to successfully recruit qualified employees as one of the most important factors influencing success and business growth and are therefore seriously concerned about ability to obtain and retain their workforce (Hornsby \& Kuratko, 2003; Williamson, Cable, \& Aldrich, 2002; Williamson, 2000). Staffing research focusing on small business is scarce (Vorman, 2004), but a large number of researches dwelt on recruitment in large organizations. A significant number of them found that many managers use subjective criteria for selection, allowing their personal interests to influence their decision-making. Cardon and Stevens (2004) observe that majority of small business employees come from the personal networks of the owner/manager, although they note that this offered benefits such as shared values and a common ground. Small employers tend to recruit as required. They do not have formal recruitment schemes and are not tied to any set of recruitment programmes; therefore, vacancies may occur at any time of the year. Small companies may also not have a formal recruitment brochure or application form. Interviews are likely to be informal and staff may not be trained in interview skills; therefore candidates will need to make sure that they bring out their strongest selling points and ask lots of questions (Kent \& Careers, 2008). 
Common to the findings of Williams and Owen (1997), Stewart and Knowles (2000), through interviews, establish that recruitment activities undertaken by SMEs generally relied on newspaper advertisements to generate applicants. SMEs rely heavily upon the interview, which concurs with Cardon and Stevens (2004) position that small employers still consider the interview as an essential part of the selection process. Recruitment tends to occur informally in small firms, drawing on networks of family members, friends and neighbors for staffing the enterprise, particularly in positions requiring unskilled and semi-skilled workers. In view of the limited scope for skilled and professional personnel in most of the small firms studied, it appears that more formalized recruitment strategies are rarely needed. This confirms the findings by researchers such as Carroll, Marchington, Earnshaw, and Taylor (1999). According to Bartram, Lindley, Marshall and Foster (1995), the recruitment and selection practices used by small organizations are different from those applied by large firms. Unlike large firms, small businesses tended to use more informal and unstructured mechanisms. Employers of small businesses also consider applicants' personality characteristics such as honesty, integrity and interest in the job to be more important than ability, aptitude or attainment. Mathis and Jackson (2010) have suggested that humans are the glue that binds the other resources useful to an organization. This implies that, without the right personnel, SMEs will be found wanting in terms of performance. Spencer (2004), agreeing with Mathis and Jackson (2010), state that effective recruitment and selection are strategically important to any firm. Recruiting and selecting the wrong candidates can have extensive negative cost implications, while effective processes can contribute to a reduction in turnover and therefore increase in productivity.

Exploration of the literature regarding retention yielded several dimensions of work by researchers. According to Walker and Miler (2010), retention is the term that describes how employers ensure that employees stay on the job. Maertz and Campion (1998), note that since it is a relative concept, retention must be studied along with quitting processes. Traditionally, factors propping up turnover are poor job dissatisfaction (Holdsworth \& Cartwright, 2003), lack of organizational commitment or psychological contract, low career expectations, work-life imbalance, lack of training and development (Carbery, O'Brien \& McDonnell, 2003; Tutuncu \& Kozak, 2007; Davidson, Timo \& Wang, 2010), strained peer and supervisor relationship (Graen, Dansereau \& Minami, 1972), cultural context (Sheridan, 1992), rewards (Hansen, Smith \& Hansen, 2002), seasonality of business and nature of jobs -- that is, whether part-time, casual or seasonal (Hartman \& Yrle, 1996; Ladkin \& Juwaheer, 2000; McCabe \& Savery, 2007; Willie, Jayawardena \& Laver, 2008). Control over these factors can save organizations from bearing high cost of turnover (Davidson, Timo \& Wang, 2010).

\section{Research Hypothesis:}

Ho: Employee resourcing does not affect the performance of SMEs in Lagos State.

\section{Method}

A descriptive survey research design was employed in the study. According to Rubin and Babbie (2001), survey research design is a scientific method of inquiry in which the researcher selects a sample of respondents and administers a standardized research instrument on them. The survey research method is appropriate for non-observable behaviours such as 
that under study. It is also appropriate for studies that have individuals/people as the units of analysis (Rubin \& Babbie, 2001). The choice of Lagos State is due to its strategic importance to Nigeria's economy. It is the economic nerve centre of Nigeria. Lagos is Nigeria's most prosperous city, and much of the nation's wealth and economic activity are concentrated here. The population of the study comprised 2,670 SMEs' owners/managers operating in Lagos State, Nigeria as compiled by Lagos State Ministry of Commerce and Industry (Lawal, 2011). Specifically, the study covers manufacturing, servicing, and trading SMEs in various local government areas in Lagos State, Nigeria. The researcher adopted stratified and simple random sampling techniques for selecting the sample size because SMEs are not homogeneous in characteristics. Stratified sampling has the advantage of external (extrinsic) validity and generalization. Small and medium-sized enterprises (SMEs) are a very heterogeneous group of businesses usually operating in the servicing, trading, and manufacturing sectors (Gushibet, 2010). According to Fagbohungbe (2002), where a population of study has heterogeneous characteristics, that is, there are subgroups that are not the same within the population, and to make selection of samples bias free, the researcher resorts to the use of stratified sampling technique. Hence, the population was stratified into three subgroups: manufacturing, servicing, and trading. Subsequently, samples were randomly selected from sub samples from each stratum.

Table 1. Questionnaire Distribution Statistics

\begin{tabular}{|c|c|c|c|c|}
\hline $\begin{array}{c}\text { Serial } \\
\text { No. }\end{array}$ & $\begin{array}{c}\text { Category of } \\
\text { SMEs }\end{array}$ & $\begin{array}{c}\text { Questionnaire } \\
\text { Distributed }\end{array}$ & $\begin{array}{c}\text { Questionnaire } \\
\text { Returned }\end{array}$ & $\begin{array}{c}\text { Percentage of } \\
\text { Response }\end{array}$ \\
\hline 1. & Manufacturing & 150 & 86 & 57.3 \\
\hline 2. & Servicing & 150 & 103 & 68.7 \\
\hline 3. & Trading & 150 & 68 & 45.3 \\
\hline & Total & 450 & 257 & 57.11 \\
\hline
\end{tabular}

Source: Developed by the author

Data for the study were gathered through primary and secondary sources. The primary data were generated from a combination of survey questionnaires and semi-structured interviews of small business owners/managers to assess their human employee resourcing practices, while secondary data collected from journal articles' research findings on SMEs, textbooks, news bulletin, newspapers as well as internet form the tertiary data for the study. The instrument is divided into two sections: A and B. Section A is on employee resourcing (ER), comprising human resource planning, recruitment \& selection, and employee retention with ten (10) items. Section B organizational performance; ten (12) items and Section C combines the demographic profiles of the SMEs and the owners/managers. Likert 4-point Scale was used to measure the opinions of small business owners/managers with respect to independent variable (ER practices) while Likert 5-point Scale was used for the dependent variable (organizational performance). The interview schedule consists of structured and unstructured questions. 


\section{Results}

Table 2. Opinions of respondents on employee resourcing and organizational performance of SMEs

\begin{tabular}{|c|c|c|c|c|c|c|c|}
\hline Statement & $\mathbf{N}$ & SA & $\mathbf{A}$ & D & SD & MIS & STD \\
\hline $\begin{array}{l}\text { Job to be performed is broken } \\
\text { into smaller units and well } \\
\text { understood before embarking on } \\
\text { employment process (job } \\
\text { analysis) }\end{array}$ & 251 & $\begin{array}{c}142 \\
(56.5 \%)\end{array}$ & $\begin{array}{c}85 \\
(33.9 \%)\end{array}$ & $\begin{array}{c}17 \\
(6.8 \%)\end{array}$ & $\begin{array}{c}7 \\
(2.8 \%)\end{array}$ & 3.44 & .74 \\
\hline $\begin{array}{l}\text { Employees are sourced using } \\
\text { recommendations from existing } \\
\text { employees and family members }\end{array}$ & 251 & $\begin{array}{c}90 \\
(35.9 \%)\end{array}$ & $\begin{array}{c}86 \\
(33.5 \%)\end{array}$ & $\begin{array}{c}63 \\
(25.1 \%)\end{array}$ & $\begin{array}{c}12 \\
(4.8 \%)\end{array}$ & 3.01 & .89 \\
\hline $\begin{array}{l}\text { Job is fully explained to the } \\
\text { prospective employee during } \\
\text { employee selection (realistic job } \\
\text { preview) }\end{array}$ & 250 & $\begin{array}{c}88 \\
(35.2 \%)\end{array}$ & $\begin{array}{c}116 \\
(46.4 \%)\end{array}$ & $\begin{array}{c}41 \\
(16.4 \%)\end{array}$ & $\begin{array}{c}5 \\
(2.0 \%)\end{array}$ & 3.15 & .759 \\
\hline $\begin{array}{l}\text { Interview is a regular feature in } \\
\text { the selection process }\end{array}$ & 251 & $\begin{array}{c}136 \\
(54.2 \%)\end{array}$ & $\begin{array}{c}103 \\
(41.0 \%)\end{array}$ & $\begin{array}{c}9 \\
(3.6 \%)\end{array}$ & $\begin{array}{c}3 \\
(1.2 \%)\end{array}$ & 3.48 & .63 \\
\hline $\begin{array}{l}\text { Job applicants are subjected to } \\
\text { employment test before selection } \\
\text { is made }\end{array}$ & 251 & $\begin{array}{c}110 \\
(43.8 \%)\end{array}$ & $\begin{array}{c}111 \\
(44.2 \%)\end{array}$ & $\begin{array}{c}23 \\
(9.2 \%)\end{array}$ & $\begin{array}{c}7 \\
(2.8 \%)\end{array}$ & 3.29 & .75 \\
\hline $\begin{array}{l}\text { Human resource plan determines } \\
\text { the level of employment }\end{array}$ & 247 & $\begin{array}{c}110 \\
(44.5 \%)\end{array}$ & $\begin{array}{c}107 \\
(43.3 \%)\end{array}$ & $\begin{array}{c}23 \\
(9.3 \%)\end{array}$ & $\begin{array}{c}7 \\
(2.8 \%)\end{array}$ & 3.30 & .75 \\
\hline $\begin{array}{l}\text { The major source of recruitment } \\
\text { is internal }\end{array}$ & 250 & $\begin{array}{c}76 \\
(30.4 \%)\end{array}$ & $\begin{array}{c}82 \\
(32.8 \%)\end{array}$ & $\begin{array}{c}68 \\
(27.2 \%)\end{array}$ & $\begin{array}{c}24 \\
(9.6 \%)\end{array}$ & 2.84 & .97 \\
\hline $\begin{array}{l}\text { There has been a great difficulty } \\
\text { retaining skilled employees }\end{array}$ & 247 & $\begin{array}{c}85 \\
(34.4 \%)\end{array}$ & $\begin{array}{c}94 \\
(38.1 \%)\end{array}$ & $\begin{array}{c}59 \\
(23.9 \%)\end{array}$ & $\begin{array}{c}9 \\
(3.6 \%)\end{array}$ & 2.98 & .86 \\
\hline $\begin{array}{l}\text { Job vacancies are seldom } \\
\text { advertised }\end{array}$ & 244 & $\begin{array}{c}73 \\
(29.9 \%)\end{array}$ & $\begin{array}{c}108 \\
(44.3 \%)\end{array}$ & $\begin{array}{c}48 \\
(19.7 \%)\end{array}$ & $\begin{array}{c}15 \\
(6.1 \%)\end{array}$ & 2.98 & .86 \\
\hline
\end{tabular}




\begin{tabular}{|c|c|c|c|c|c|c|c|}
\hline Statement & N & SA & A & D & SD & MIS & STD \\
\hline $\begin{array}{l}\text { Performance of the organisation } \\
\text { can be linked directly with how } \\
\text { employees are selected and } \\
\text { motivated }\end{array}$ & 247 & 123 & 103 & 17 & 4 & 3.40 & .69 \\
$(49.8 \%)$ & $(41.7 \%)$ & $(6.9 \%)$ & $(1.6 \%)$ & & \\
\hline
\end{tabular}

Source: Field Survey, 2012. Legend: N=Total Response, SA=Strongly Agree, A=Agree, $\mathrm{D}=$ Disagree, $\mathrm{SD}=$ Strongly Disagree

From table 2 above, it is revealed that sampled SMEs conducted job analysis. This is not surprising as job specifications and descriptions used in job vacancy advertisements are the products of job analysis. It also shows that employees are sourced by referrals from employees and family members. This is typical of recruiting among SMEs which rely more on informal means of getting the needed staff. It is also shown from table 2 that there is a realistic job preview during interview process. This is very important because employees whose job demands are higher than his expectations may soon be frustrated and quit the job. It is also revealed from table 2 above that interview is a regular feature of their selection process. This implies that interview is the most popular selection technique among the participating SMEs, even though it is fraught with many shortcomings which could be overcome with adequate interviewing skills. In addition to job interview, applicants are subjected to employment test before selection is made. Evidence from table 2 above shows that sampled SMEs embark on recruitment and selection process with adequate human resource/manpower need analysis of the organization. Going by the available literature, one of the major human resource management challenges facing SMEs is employee retention. Most often, SMEs lose talented staff to large organizations as the wherewithal to attract and retain high quality employee is most often lacking. The autocratic style of leadership among Nigerian SMEs owners/managers hardly encourages opposing views and this does not allow for participative style of management which has been considered one of the best methods of motivating employees (Lawal, 2005). It is evident from table 2 above that employee retention has been a major problem of SMEs as the respondents of the sampled SMEs indicated that they have been facing a great difficulty retaining key personnel. Job vacancy advertisement is one of the methods of external recruitment. It shows that majority of the respondents supported the statement that job vacancies are seldom advertised. To ascertain if performance of the organizations sampled SMEs can be directly linked with how employees are selected and motivated, it shows from table 2 above that the performance of the sampled SMEs can be linked to how employees are selected and motivated. This is because, of the 247 respondents of sampled SMEs, $226(91.5 \%)$ agreed and 21 (8.5\%) disagreed that employee resourcing activities comprising human resource planning, recruitment, selection and retention have a combined effect on the performance of sampled SMEs. This is also confirmed by mean 3.40 and standard deviation of 0.69 . 


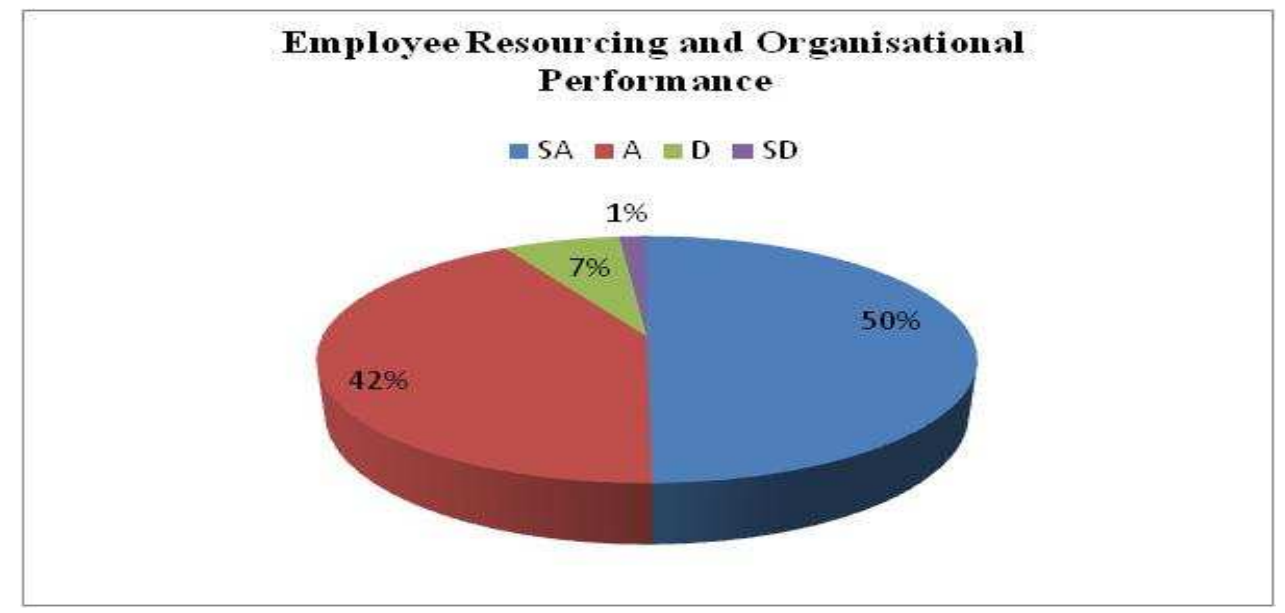

Legend: SA-Strongly Agreed, A-Agreed, D-Disagreed, SD-Strongly Disagreed.

Figure 2. Employee Resourcing and Organizational Performance

\subsection{Demographic Profile of Respondents}

Demographic profile of respondents is the background knowledge of the characteristics of the respondents and it is very important in order to place in proper perspective some demographic factors that could influence opinions. Table 3 summarizes the demographic profiles of the respondents and that of their organizations.

Table 3. Organizational and Owner/Managers' Information

\begin{tabular}{|c|l|c|c|}
\hline Organization Information & \multicolumn{1}{|c|}{ Variables } & Frequency & Percentage \% \\
\hline \multirow{2}{*}{ No. of Employees } & Fewer than 20 & 118 & 45.9 \\
$20-50$ & 52 & 20.2 \\
& $51-100$ & 29 & 11.3 \\
& $101-200$ & 14 & 5.5 \\
& $201-300$ & 25 & 9.7 \\
& No Response & 19 & 7.4 \\
\hline \multirow{2}{*}{ Sector } & Manufacturing & 86 & 33.5 \\
& Servicing & 103 & 40.1 \\
& Trading & 48 & 18.6 \\
& No Response & 19 & 7.8 \\
\hline \multirow{2}{*}{ Age of the organisation } & Less than 1 year ago & 20 & 8.1 \\
\hline
\end{tabular}




\begin{tabular}{|c|c|c|c|}
\hline & $\begin{array}{l}1 \text { but less than } 2 \text { years ago } \\
2 \text { but less than } 3 \text { years ago } \\
3 \text { but less than } 4 \text { years ago } \\
5 \text { but less than } 10 \text { years ago } \\
\text { Above } 10 \text { years } \\
\text { No Response }\end{array}$ & $\begin{array}{l}23 \\
32 \\
45 \\
48 \\
68 \\
22\end{array}$ & $\begin{array}{r}9.8 \\
13.6 \\
19.1 \\
20.4 \\
28.9 \\
8.6\end{array}$ \\
\hline Relationship with Employees & $\begin{array}{l}\text { Close family members } \\
\text { Distant Relations } \\
\text { Friends } \\
\text { (Not Related) } \\
\text { No Response }\end{array}$ & $\begin{array}{r}19 \\
32 \\
30 \\
143 \\
32\end{array}$ & $\begin{array}{r}7.5 \\
12.6 \\
11.8 \\
55.6 \\
12.5\end{array}$ \\
\hline Title in the Organization & $\begin{array}{l}\text { No Specialist HR Manager } \\
\text { HR Manager } \\
\text { Personnel Manager } \\
\text { Employee Relations } \\
\text { Manager } \\
\text { Administrative Manager } \\
\text { No Response }\end{array}$ & $\begin{array}{l}63 \\
54 \\
29 \\
18 \\
59 \\
34\end{array}$ & $\begin{array}{r}28.3 \\
24.2 \\
13.0 \\
8.1 \\
26.4 \\
13.2\end{array}$ \\
\hline Sex & $\begin{array}{l}\text { Male } \\
\text { Female } \\
\text { Missing Data }\end{array}$ & $\begin{array}{l}163 \\
72 \\
22\end{array}$ & $\begin{array}{c}63.4 \\
28.0 \\
8.6\end{array}$ \\
\hline Age & $\begin{array}{l}\text { Less than } 20 \\
20-29 \text { years } \\
30-49 \\
50-59 \\
60 \text { and Above } \\
\text { Missing Data }\end{array}$ & $\begin{array}{l}13 \\
41 \\
98 \\
68 \\
14 \\
23\end{array}$ & $\begin{array}{r}5.1 \\
16.0 \\
38.1 \\
26.5 \\
5.4 \\
8.9\end{array}$ \\
\hline
\end{tabular}




\begin{tabular}{|c|c|c|c|}
\hline \multirow[t]{5}{*}{ Marital Status } & Single & 58 & 22.6 \\
\hline & Married & 166 & 64.6 \\
\hline & Separated & 7 & 2.7 \\
\hline & Divorced & 2 & 0.7 \\
\hline & Missing Data & 24 & 9.4 \\
\hline \multirow[t]{6}{*}{ Status in the Organization } & Chief Executive & 55 & 21.4 \\
\hline & Owner/Manager & 50 & 19.5 \\
\hline & Manager & 31 & 12.0 \\
\hline & Assistant Manager & 35 & 13.6 \\
\hline & Supervisor & 48 & 18.7 \\
\hline & Missing Data & 38 & 14.8 \\
\hline \multirow[t]{6}{*}{ Qualifications } & $\mathrm{NCE}$ & 7 & 2.7 \\
\hline & OND & 29 & 11.4 \\
\hline & Bachelor & 108 & 42.0 \\
\hline & Masters & 72 & 28.0 \\
\hline & Others & 14 & 5.4 \\
\hline & Missing Data & 27 & 10.5 \\
\hline \multirow{6}{*}{$\begin{array}{c}\text { Length of Service in the } \\
\text { Organization }\end{array}$} & Less than 1 year & 40 & 15.6 \\
\hline & $1-5$ years & 102 & 39.7 \\
\hline & $6-10$ years & 60 & 23.3 \\
\hline & $11-15$ years & 14 & 5.5 \\
\hline & 16 and Above & 18 & 7.0 \\
\hline & Missing Data & 23 & 8.9 \\
\hline
\end{tabular}

Source: Field Survey, 2012.

From 238 respondents of the sampled SMEs, 118 (45.9\%) had fewer than 20 employees, while $139(54.1 \%)$ had more than 20 employees. This shows that most of the sampled SMEs can be categorized as medium enterprises. Above 40\% (103 of 257) of the participating SMEs operated in the service sector, $33.5 \%$ (86 of 257) in the manufacturing, 18.6\% (48 of 257 ) in the trading sector and $7.8 \%$ (20 of 257) missing data. Almost $30 \%$ (68 of 257) of 
sampled SMEs were above 10 years of in operations. This shows that most of the sampled SMEs have been in operations for quite some time as they have been able to survive the major challenges of the business. A little above 55\% (143 of 257) of the total number of employees were not related in any way to the owners/managers of the participating SMEs. Almost 30\% (63 of 257) of the sampled SMEs did not have a specialist in charge of HRM. More than $60 \%$ (163 of 257) of the owners/managers of sampled SMEs were male, while 28\% (72 of 257) were female and 8.6\% (22 of 257) missing data. Almost 40\% (98 of 257) of the owners/managers of participating SMEs were between 30-49 age brackets. Of the 257 of sampled owners/managers of participating SMEs, more than $60 \%$ (166 of 257) were married. Above 20\% (55 of 257) of the respondents was designated chief executive, which shows that the owners of the business are not separated from the management. Above 40\% (108 of 257) respondents had Bachelor degree. Of 257 participating owners/managers of sampled SMEs, almost $40 \%$ (102 of 257) had spent between 1-5 years in the organization. This shows most of the employees are relatively new in the organization.

Table 4. Organizational Performance

\begin{tabular}{|c|c|c|c|c|c|c|c|c|}
\hline $\begin{array}{c}\text { Performance } \\
\text { Criteria }\end{array}$ & $\mathbf{N}$ & VH & $\mathbf{H}$ & $\mathbf{M}$ & $\mathbf{L}$ & VL & MIS & STD \\
\hline Profitability & 238 & $\begin{array}{c}61 \\
(25.6 \%)\end{array}$ & $\begin{array}{c}100 \\
(42.0 \%)\end{array}$ & $\begin{array}{c}60 \\
(25.2 \%)\end{array}$ & $\begin{array}{c}13 \\
(5.5 \%)\end{array}$ & $\begin{array}{c}4 \\
(1.7 \%)\end{array}$ & 3.84 & .93 \\
\hline Financial Strength & 236 & $\begin{array}{c}52 \\
(22.0 \%)\end{array}$ & $\begin{array}{c}91 \\
(38.6 \%)\end{array}$ & $\begin{array}{c}57 \\
(24.2 \%)\end{array}$ & $\begin{array}{c}30 \\
(12.7 \%)\end{array}$ & $\begin{array}{c}6 \\
(2.5 \%)\end{array}$ & 3.65 & 1.04 \\
\hline $\begin{array}{l}\text { Operating } \\
\text { efficiency }\end{array}$ & 238 & $\begin{array}{c}46 \\
(19.3 \%)\end{array}$ & $\begin{array}{c}103 \\
(43.3 \%)\end{array}$ & $\begin{array}{c}67 \\
(28.2 \%)\end{array}$ & $\begin{array}{c}21 \\
(8.8 \%)\end{array}$ & $\begin{array}{c}1 \\
(0.4 \%)\end{array}$ & 3.72 & .89 \\
\hline Performance stability & 238 & $\begin{array}{c}35 \\
(14.7 \%)\end{array}$ & $\begin{array}{c}101 \\
(42.4 \%)\end{array}$ & $\begin{array}{c}90 \\
(37.8 \%)\end{array}$ & $\begin{array}{c}12 \\
(5.0 \%)\end{array}$ & - & 3.67 & .79 \\
\hline $\begin{array}{l}\text { Public image and } \\
\text { goodwill }\end{array}$ & 239 & $\begin{array}{c}52 \\
(21.8 \%)\end{array}$ & $\begin{array}{c}98 \\
(41.0 \%)\end{array}$ & $\begin{array}{c}60 \\
(25.1 \%)\end{array}$ & $\begin{array}{c}23 \\
(9.6 \%)\end{array}$ & $\begin{array}{c}6 \\
(2.5 \%)\end{array}$ & 3.70 & .97 \\
\hline Staff morale & 235 & $\begin{array}{c}39 \\
(16.6 \%)\end{array}$ & $\begin{array}{c}80 \\
(34.0 \%)\end{array}$ & $\begin{array}{c}77 \\
(32.8 \%)\end{array}$ & $\begin{array}{c}31 \\
(13.2 \%)\end{array}$ & $\begin{array}{c}8 \\
(3.4 \%)\end{array}$ & 3.47 & 1.03 \\
\hline $\begin{array}{c}\text { Growth rate of } \\
\text { number of }\end{array}$ & 235 & $\begin{array}{c}17 \\
(7.3 \%)\end{array}$ & $\begin{array}{c}77 \\
(32.8 \%)\end{array}$ & $\begin{array}{c}85 \\
(36.2 \%)\end{array}$ & $\begin{array}{c}43 \\
(17.9 \%)\end{array}$ & $\begin{array}{c}13 \\
(5.5 \%))\end{array}$ & 3.18 & .98 \\
\hline
\end{tabular}




\section{1ll Macrothink}

Journal of Entrepreneurship and Business Innovation

ISSN 2332-8851

2014, Vol. 1, No. 1.

\begin{tabular}{|c|c|c|c|c|c|c|c|c|}
\hline $\begin{array}{c}\text { Performance } \\
\text { Criteria }\end{array}$ & $\mathbf{N}$ & VH & $\mathbf{H}$ & $\mathbf{M}$ & $\mathbf{L}$ & VL & MIS & STD \\
\hline \multicolumn{9}{|l|}{ employees } \\
\hline Adaptability & 234 & $\begin{array}{c}20 \\
(8.5 \%)\end{array}$ & $\begin{array}{c}83 \\
(35.5 \%)\end{array}$ & $\begin{array}{c}97 \\
(41.5 \%)\end{array}$ & $\begin{array}{c}29 \\
(12.4 \%)\end{array}$ & $\begin{array}{c}5 \\
(2.1 \%)\end{array}$ & 3.36 & .88 \\
\hline Innovativeness & 233 & $\begin{array}{c}35 \\
(15.1 \%)\end{array}$ & $\begin{array}{c}82 \\
(35.2 \%)\end{array}$ & $\begin{array}{c}81 \\
(34.8 \%)\end{array}$ & $\begin{array}{c}32 \\
(13.7 \%)\end{array}$ & $\begin{array}{c}3 \\
(1.3 \%)\end{array}$ & 3.49 & .95 \\
\hline $\begin{array}{l}\text { Level of } \\
\text { indebtedness }\end{array}$ & 231 & $\begin{array}{c}15 \\
(6.6 \%)\end{array}$ & $\begin{array}{c}37 \\
(16.0 \%)\end{array}$ & $\begin{array}{c}53 \\
(22.9 \%)\end{array}$ & $\begin{array}{c}80 \\
(34.6 \%)\end{array}$ & $\begin{array}{c}46 \\
(19.9 \%)\end{array}$ & 2.55 & 1.17 \\
\hline Customer patronage & 238 & $\begin{array}{c}44 \\
(18.5 \%)\end{array}$ & $\begin{array}{c}93 \\
(39.0 \%)\end{array}$ & $\begin{array}{c}78 \\
(32.7 \%)\end{array}$ & $\begin{array}{c}19 \\
(8.0 \%)\end{array}$ & $\begin{array}{c}4 \\
(1.9 \%)\end{array}$ & 3.65 & .93 \\
\hline $\begin{array}{l}\text { Ability to raise } \\
\text { capital }\end{array}$ & 235 & $\begin{array}{c}41 \\
(17.4 \%)\end{array}$ & $\begin{array}{c}80 \\
(34.2 \%)\end{array}$ & $\begin{array}{c}57 \\
(24.3 \%)\end{array}$ & $\begin{array}{c}45 \\
(19.1 \%)\end{array}$ & $\begin{array}{c}12 \\
(5.0 \%)\end{array}$ & 3.40 & 1.13 \\
\hline
\end{tabular}

Source: Field Survey, 2012 Legend: N=Total Response, VH=Very High, H=High,

$\mathrm{M}=$ Moderate, $\mathrm{VL}=$ Very Low

Evidence from table 4 above shows that profitability of sampled SMEs improved due to employee resourcing (ER) practices. Using financial strength as a parameter for measuring organizational performance, most of the respondents indicated that financial strength of their organizations was high as a result of employee resourcing practices. Another important variable used to assess organizational performance is operating efficiency. It is also evident from table 4 that operating efficiency of sampled SMEs was high. Performance stability is the consistency of an organization in maintaining a particular performance level over a period of time. Majority of owners/managers of sampled SMEs indicated that the performance of their organizations was stable over a period of time. From table 4 above, it is revealed that public image and goodwill of sampled SMEs was high. It is also revealed that sampled owners/managers indicated that staff morale was high. Quantitatively, increase in the number of employees may be used as a parameter to measure the performance of an organization, since it is believed that an organization that is struggling to survival is not likely to employ more staff. From table 4 above, it is evident that the growth rate of number of employees of sampled SMEs could be considered high. One of the useful attributes of SMEs is adaptability, which is the ability of an organization to adjust easily to the vagaries/turbulence of external environment. From table 4 above, it is evident that a significant number of the respondents opined that adaptability of their SMEs was quite high, which could be, among other things, as 
a result of employee resourcing practices. From table 4 above, it is revealed that innovativeness was high, which could be as a result of employee resourcing practices, among others, adopted by the owners/managers of the sampled SMEs. From table 4 above, it shows that the level of indebtedness of the sampled SMEs was low. Customer patronage is also an important indicator of organizational performance. The more customer patronage a business enjoys the more the sales, especially if the organization has the largest market share of the product. It shows from table 4 above that customer patronage of sampled SMEs was high. Inadequate capital has been the bane of performance of SMEs. Hence, it is a competitive edge for any organization to be able to raise enough capital. It is evident from table 4 above that ability of sampled SMEs to raise capital was high.

\subsection{Discussion of findings}

Ho: Employee resourcing does not affect the performance of SMEs in Lagos State.

$\mathrm{H}_{1}$ : Employee resourcing affects the performance of SMEs in Lagos State.

Table 5. Regression Analysis

$\mathbf{R}=\mathbf{. 1 1 3}$

$\mathbf{R}^{2=.013}$

Adjusted $R^{2}=.009$

Standard Error of Estimate $=\mathbf{. 6 8 4}$

\begin{tabular}{|rr|r|r|r|r|r|r|}
\hline Model & \multicolumn{1}{|c|}{$\begin{array}{c}\text { Sum of } \\
\text { Squares }\end{array}$} & \multicolumn{1}{c|}{ Df } & \multicolumn{1}{c|}{$\begin{array}{c}\text { Mean } \\
\text { Square }\end{array}$} & F & Sig. & Remarks \\
\hline $1 \quad$ Regression & 1.423 & 1 & 1.423 & 3.044 & $.082(\mathrm{a})$ & \\
& Residual & 109.826 & 235 & .467 & & & \\
\hline & Total & 111.249 & 236 & & & & \\
\hline
\end{tabular}

a. Predictors: (Constant), Employee Resourcing. Non significant at F $(1,235)=3.044 ; \mathrm{P}>0.05$

b. Dependent Variable: Organizational Performance

The regression analysis result shows that employee resourcing which is a combination of human resource planning, recruitment and selection, and employee retention did not make significant contribution to organizational performance considering a p-value of 0.082 , which is greater than $\alpha=0.05$. The result further shows that the effect did occur by chance as it gave the F-ratio value of 3.044 showing the strength of the independent variable as a non-predictor of organizational performance of sampled SMEs. The focus of the hypothesis was to ascertain the contribution of employee resourcing to organizational performance of sampled SMEs in Lagos State. The result shows that there is a moderate association $(R=0.113)$ of 
independent variable and dependent variable and that employee resourcing did not have significant contribution to organizational performance of participated SMEs. The result further shows that the relationship did occur by chance as it gave the F-ratio value of 3.044 showing employee resourcing as a non-predictor of organizational performance of sampled SMEs. The major contribution of this study is that even though there is a relationship between employee resourcing and performance of sampled SMEs, it is not strong enough to be used to predict the performance of sampled SMEs.

Table 6. Research Statement, Findings, Previous Literature and Implications

\begin{tabular}{|c|c|c|c|}
\hline $\begin{array}{l}\text { Research } \\
\text { Statement }\end{array}$ & Findings & $\begin{array}{c}\text { Previous } \\
\text { Literature }\end{array}$ & Implications \& Conclusion \\
\hline $\begin{array}{c}\text { Employee } \\
\text { Resourcing and } \\
\text { organizational } \\
\text { performance of } \\
\text { SMEs }\end{array}$ & $\begin{array}{l}\text { There is a mild } \\
\text { correlation }(.113) \\
\text { between } \\
\text { employee } \\
\text { resourcing and } \\
\text { organizational } \\
\text { performance of } \\
\text { sampled SMEs } \\
\text { but not a strong } \\
\text { predictor of } \\
\text { performance. }\end{array}$ & $\begin{array}{c}\text { Spencer (2004) } \\
\text { Davidson, Timo, } \\
\text { \& Wang (2010), } \\
\text { Mathis \& } \\
\text { Jackson (2010) }\end{array}$ & $\begin{array}{l}\text { Humans are the glue that hold or } \\
\text { bind the other resources therefore, } \\
\text { without the right personnel, SMEs } \\
\text { will be found wanting in terms of } \\
\text { competent workforce. Recruiting } \\
\text { and selecting the wrong candidates } \\
\text { can have excessive negative cost } \\
\text { implications, while effective } \\
\text { processes employee resourcing can } \\
\text { contribute to a reduction in } \\
\text { turnover and therefore increase } \\
\text { productivity }\end{array}$ \\
\hline
\end{tabular}

\section{Conclusion and Recommendations}

There is an association between employee resourcing; a combination of human resource planning, recruitment and selection, and employee retention and performance of small and medium enterprises. Furthermore, although employee resourcing has a relationship with performance as the study reveals, it is not a good predictor of performance of sampled SMEs in Lagos State, Nigeria. Human resource planning (HRP) plays an important role in helping an organization to determine the level of employment and the caliber of employees required by the organization. In order to have the right employees, at the right time, at the right place, HRP should be carried out comprehensively. Recruitment and selection is unique in SMEs because of lack of economy of scale, liability of smallness and newness. Hence, attracting, recruiting, and retaining skilled employees into SMEs is very challenging as it is evident from the findings that employee retention is one of the major problems of SMEs. Recruitment, selection and retention are significant to performance of organizations and most sampled SMEs appreciated the need for effective employee resourcing practices but there were other more important issues calling for the attention of small business owners/managers, hence it is recommended that employee resourcing functions should be outsourced to a professional human resource management (HRM) outfit which has the structure and networks to source 
for competent staff if the organization does not have the wherewithal to employ HRM specialists. In addition, succession planning, an offshoot of human resource planning should be taken seriously. Retention of key employees was a major issue among sampled SMEs in Lagos State, Nigeria. Therefore, long term personal loan should be given to employees of SMEs through a financial institution which will monitor loan utilization and recovery even if an employee leaves the organization. This has the advantage of keeping the employees on the job as long as the loan lasts and has the benefit of helping employees meet the long term financial goal of building a house and financing the children education, even buying a car, which is what large organizations dangle to attract, motivate and retain skilled employees.

\section{References}

Applebaum, H. and Kamal, R. (2000) "An analysis of the utilization and incentives in small business" Journal of Management Development, 19(9/10), 733-763.

Armstrong, M. (2001). A handbook of human resource management Practice (8 ${ }^{\text {th }}$ ed.). London: Kogan Page.

Armstrong, M. (2012). A handbook of human resource management Practice (12 ${ }^{\text {th }}$ ed.). London: Kogan Page.

Barbie, E. (2001). The practice of social research $\left(9^{\text {th }}\right.$ edition) Toronto: Nelson Thomson Learning.

Barney, J. B. (1991). "Firm resources and sustained competitive advantage." Journal of Management, 17(1), 99-121.

Bartram, D., Lindley, P.A., Marshall, L., and Foster, J. (1995) "The recruitment and selection of young people by small businesses" Journal of Occupational and Organizational Psychology 68(4), 339-440.

Burns, P. (2001). Entrepreneurship and small business, Palgrave: Basingstoke

Candon, M., and Stevens, C. (2004) "Managing human resource in small organisations: What do we know?" Human Resource Management Review, (14), 295-323.

Carbery, R.G., O’Brien, T.N., and McDonnell, J. (2003). "Predicting hotel manager turnover cognition” Journal of Managerial Psychology, 18(7), 649-679.

Carroll, M.M. and Marchington, M., Earnshaw, J., and Taylor, S. (1999). "Recruitment in small firms: Processes, methods and problems.” Employee Relations, 21(3), 236-250.

Cooke, F.L. (2000). "Human resource strategy to improve organisational performance: A route for British firms?" ESRC Future Work Programme, Working Paper No. 9. Manchester School of Management, UMIST.

Davidson, M.C.G., Timo, N., and Wang, Y. (2010) "How much does labor turnover cost? A Case Study of Australian Four-Five Star Hotels." International Journal of Contemporary 
Hospitality Management, 22(4), 451-466. Doi: 10.1108/09596111011042686

Delery, J.E. and Doty, D.H. (1996). "Modes of theorizing in strategic human resource management: Tests of universalistic, contingency, and configurational performance predictions." Department of International Development and the Treasury Ministry of United Kingdom, London, June 19.

Drucker, P.F. (1974). Managing for result, New York: Pan Paper Books Ltd.

Fagbohungbe, O.B. (2002). Research methods for tertiary institutions and professional bodies Lagos: Kotleb Publishers

Fitzsimmons, J., and Fitzsimmons, M. (2003). Service management, Boston, M.A: McGraw Hill.

Garaen, G., Dansereau, F., Minami, T. (1972). "Dysfunctional leadership styles" Organizational Behavior and Human Performance, 7, 216-228.

Gushibet, S. (2010) "Building small and medium scale enterprises: A Strategy for economic development in Nigeria” Jos Journal of Economics, (4), 1-15.

Hansen, F., Smith, M., and Hansen, R. B. (2002). "HRM and Universalism: Is there one best way? Resource for Niagara's hospitality industry," International Journal of Contemporary Hospitality, 20(3), 293-301 doi: 10.1108/09596110810866109.

Hartmen, S., and Yrle, A. (1996). "Can the Hobo phenomena explain voluntary turnover" International Journal of Contemporary Hospitality Management, 8(4), 11-16.

Holdsworth, L., and Cartwright, S. (2003). "Empowerment, Stress, and Satisfaction: An Exploratory Study of a Call Center" Leadership and Organizational Development Journal, (3), $13-22$.

Hornsby, J.S., and Kuratko, D.F. (2003). "Human resource management in U.S. small business: A Replication and extension" Journal of Development Entrepreneurship, 8 (1), 73 -92 .

Hsu, I.C., Lin, C.Y.Y., Lawler, J.J., and Wu, S.H. (2007) "Towards a model of organizational human capital development: Preliminary evidence from Taiwan." Asia Pacific Business Review (13), 251-275.

Kaplan, R.S. and Norton, D.P. (2004). "The strategy map: Guiding to aligning intangible assets." Strategy and Leadership, 32(5), 10-17 Available from: www.emeraldinsight

Kwandavalla, P.N. (1995) Management Style, New Delhi McGraw-Hill Publishing Company limited.

Ladkin, A. and Juwaheer, T.D. (2000) "The career paths of hotel general manager in Mauritius" International Journal of Contemporary Hospitality Management, 12(2), 119-125.

Lawal, A.A. (2011). "Strategic importance of Nigerian small and medium enterprises: Separating the reality form the myth", $22^{\text {nd }}$ Lagos State Polytechnic Inaugural Lecture. 


\section{Macrothink}

Journal of Entrepreneurship and Business Innovation

ISSN 2332-8851

Lawal, A.A. (2005). "Management Practices and Organizational Effectiveness of Nigerian Small and Medium Enterprises in Lagos State" A thesis submitted to the School of Postgraduate Studies in partial fulfillment of award of Doctor of Philosophy in General Management.

Maertz, C.P. Jr., and Campion, M.A. (1998). "25 years of voluntary turnover research: A Review" Management Journal, (35), 1036-1054.

Marchington, M. and Grugulis, I. (2000). "Best practice human resource management: Perfect opportunity or dangerous illusion?" International Journal of Human Resource Management (11), 104-124.

Mathis R.L and Jackson J.H. (2010). Human Resource Management (13th ed.) US: South-Western Learning.

McCabe, V.S., and Savery, L.K. (2007). "Butterflying a new career pattern for Australia? Empirical evidences" Journal of Management Development, 26(2), 103-116.

Muse, L.A., Rutherford, M.W., Oswald, S.L., and Raymond, J.E. (2005). "Commitment to employees: Does it help or hinder small business performance?" Small Business Economics, 24 (2), 97-111.

Penrose, E.G. (1959). The theory of the growth of the firm, New York: Wiley.

Rubin, A. and Babbie, E. (2001). Research methods for social work, Australia: Wadsworth.

Schuler, R.S. and Jackson, S.E. (1987). "Linking Competitive Strategies with Human Resource Management Practices". Academy of Management Executive Vol.1, No.3, pp 207 219.

Sheridan, J.E. (1992). "Organizational culture and employee retention", Academy of Management Journal, 35(103), 1036-1054.

Spencer, J.D. (2004). Fundamentals of Staff Development, University of New England.

Tutuncu, O. and Kozak, M. (2007). "An investigation of factors affecting job satisfaction" International Journal of Hospitality \& Tourism Administration, 8(1), 1-19.

Ukenna, S., Ifeoma, N., Anionwu, C. and Olise, M.C. (2010) "Effect of investment in human capital development on organizational performance: Empirical examination of the perception of small business owners in Nigeria." European Journal of Economics, Finance and Administrative Science (26), 93 - 107.

Walker, J.R., and Miller, J.E. (2010). Supervision in the hospitality industry: Leading human resources $\left(6^{\text {th }}\right.$ Ed.). New Jersey: John Wiley \& Sons, Inc.

Williams, H. and Owen, G. (1997). "Recruitment and utilisation of graduates by small and medium sized enterprises" Department for Education \& Employment (DFEE), Research Report No. 29, October, London.

Williamson, I.O. (2000, Fall). "Employer legitimacy and recruitment success in small 


\section{Macrothink}

businesses." Entrepreneurship theory and practice, 25 (1), 27-43.

Williamson, I.O., Cable, D.M, and Aldrich, H.E. (2002). "Smaller but not necessarily weaker: How small businesses can overcome barriers to recruitment" In Katz, A. and Welbourne, T.M. (Eds.) Managing People in Entrepreneurial Organisations: Learning from the Merger of Entrepreneurship and Human Resource Management, 83-106. Amsterdam, JAI Press.

Willie, P.A., Jayawardena, C., and Laver, B. (2008). “Attracting and retaining quality human resource for Niagara's hospitality industry" International Journal of Contemporary Hospitality, 20(3), 293-301 Doi: 10.1108/09596110810866109. 